\title{
First record of Homoeographa lanceolella Ragonot (Lepidoptera: Pyralidae: Phycitinae) in Chile
}

\section{Primer registro de Homoeographa lanceolella Ragonot (Lepidoptera: Pyralidae: Phycitinae) en Chile}

\author{
HÉctor A. VARgAS ${ }^{1}$ \\ ${ }^{1}$ Departamento de Recursos Ambientales, Facultad de Ciencias Agronómicas, Universidad de Tarapacá, Casilla 6-D, Arica, \\ Chile; havargas@uta.cl; lepvargas@gmail.com
}

The Neotropical genus Homoeographa Ragonot, 1888 (Lepidoptera: Pyralidae: Phycitinae) currently includes two species: $H$. lanceolella Ragonot, 1888 from Peru and $H$. mexicana Neunzig, 1994 from Mexico (Nuss et al. 20032015). Current knowledge of the two species is restricted to the original descriptions, including the male and the female for the type species, $H$. lanceolella, and only the male holotype for $H$. mexicana, while their known distribution ranges remain restricted to the respective type localities (Heinrich 1956, Neunzig 1994).

One male and two females of $H$. lanceolella (Fig. 1-4) were collected at light in the Azapa Valley $\left(18^{\circ} 31^{\prime} \mathrm{S}, 70^{\circ} 10^{\prime} \mathrm{W}\right)$ (Fig. 5), Arica Province, in the Atacama Desert of northern Chile in 2012 and 2014, providing the first records for this species in Chile. This discovery greatly expands the range of H. lanceolella, as its type locality (Callao, Peru) is located approximately 1,300 km northwest of the Azapa Valley.

The three specimens reported here were well scaled when they were collected, suggesting that they were freshly emerged. Consequently, they do not appear to be vagrant specimens coming from the type locality. Their larvae most certainly would have matured near the sampling site, which means that the geographic range of $H$. lanceolella may include a great part of the coastal desert of southern Peru and northern Chile.

Geographic ranges restricted to the coastal desert of southern Peru and northern Chile have been documented for species of different insect orders (e.g.: Porter 1985, Stange 1989, Howden 2008). In Lepidoptera this pattern has been mentioned for species of several families, including both butterflies and moths, with ranges sometimes also including southern Ecuador (e.g.: Peña \& Ugarte 1996, Vargas et al. 2013). Thus further sampling is required in this geographic area in order to characterize better the distribution of $H$. lanceolella.

The first Chilean locality (Azapa Valley) here reported for $H$. lanceolella is in a highly human-modified area characterized by intensive agricultural activities that have strongly transformed the original habitats (Luebert \& Pliscoff 2006). Despite this high level of disturbance, some native phytophagous Lepidoptera species are able to maintain relatively high levels of abundance, sometimes associated with the capacity to use exotic hosts (Vargas 2013, Vargas \& Mundaca 2014). Although the three Chilean specimens of $H$. lanceolella were not obtained in a quantitative study, as they were fortuitously found at light, it appears that the abundance of this species is low in the sampling site as only three adults have been found in about ten years of surveying for moths in the same place. However, as the biology of its immature stages remains unknown, it is not possible to attempt to correlate the low abundance with human disturbances.

Larvae of Phycitinae are mostly leaf rollers, although a great diversity of other habits have been also reported for this group, including some species that are seed feeders, inquilines or predators (Munroe \& Solis 1998). Thus additional sampling would be useful to understand better the biology of this little-known moth in the arid environments of the Atacama Desert.

Voucher material is deposited in the "Colección Entomológica de la Universidad de Tarapacá" (IDEA), Arica, Chile.

Material examined: One male, one female Azapa, Arica, Chile, August 2014, H.A. Vargas coll. One female Azapa, Arica, Chile, October 2012, H.A. Vargas coll. 


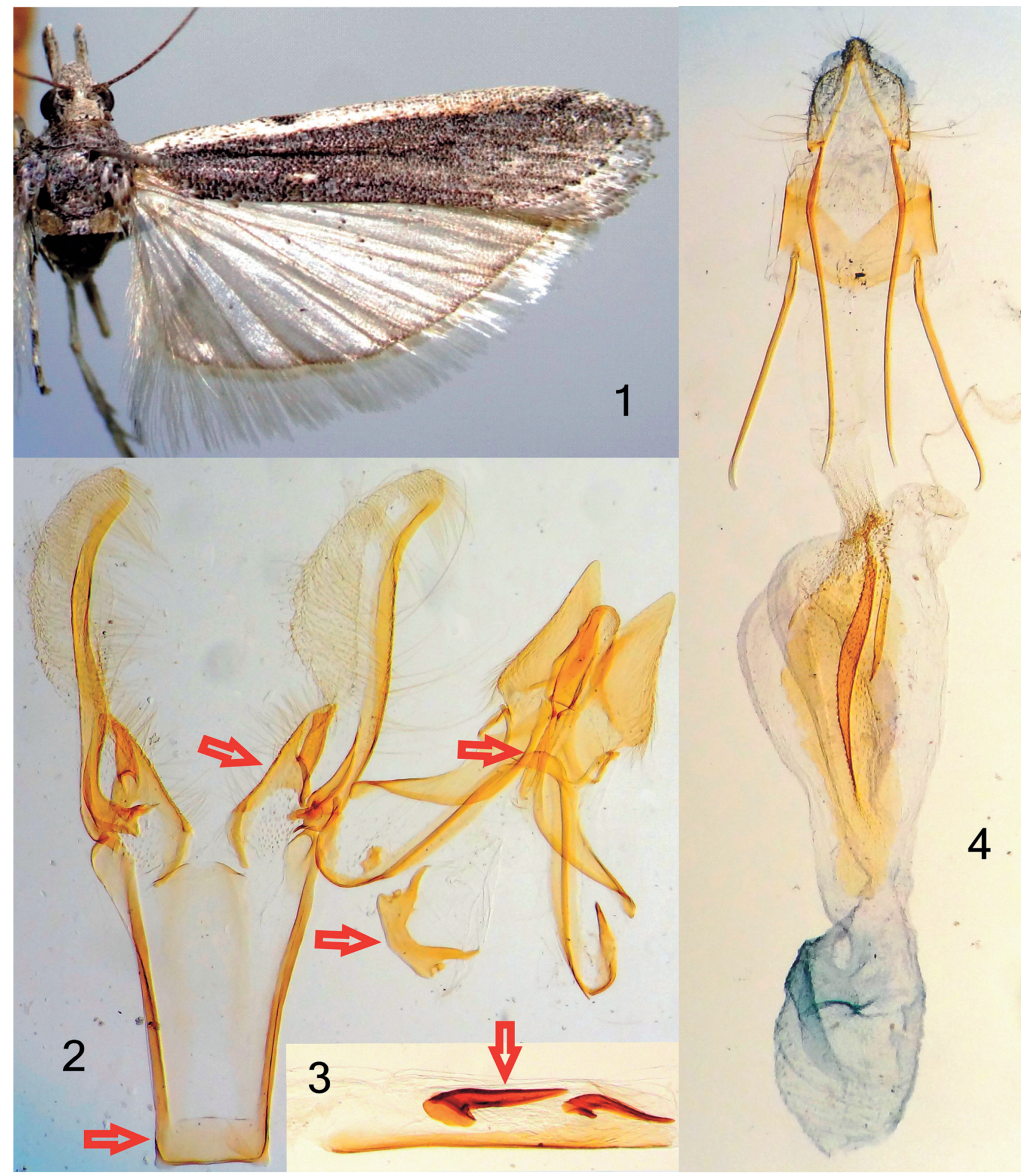

FIgURE 1-4. Homoeographa lanceolella. 1) Female adult in dorsal view; 2) male genitalia, aedeagus removed; 3) aedeagus; 4) female genitalia. Arrows in the male genitalia indicate the main morphological differences with Homoeographa mexicana.

FIgURA 1-4. Homoeographa lanceolella. 1) Hembra en vista dorsal; 2) genitalia del macho, aedeagus removido; 3) aedeagus; 4) genitalia de la hembra. Las flechas en la genitalia del macho señalan las principales diferencias morfológicas con Homoeographa mexicana. 


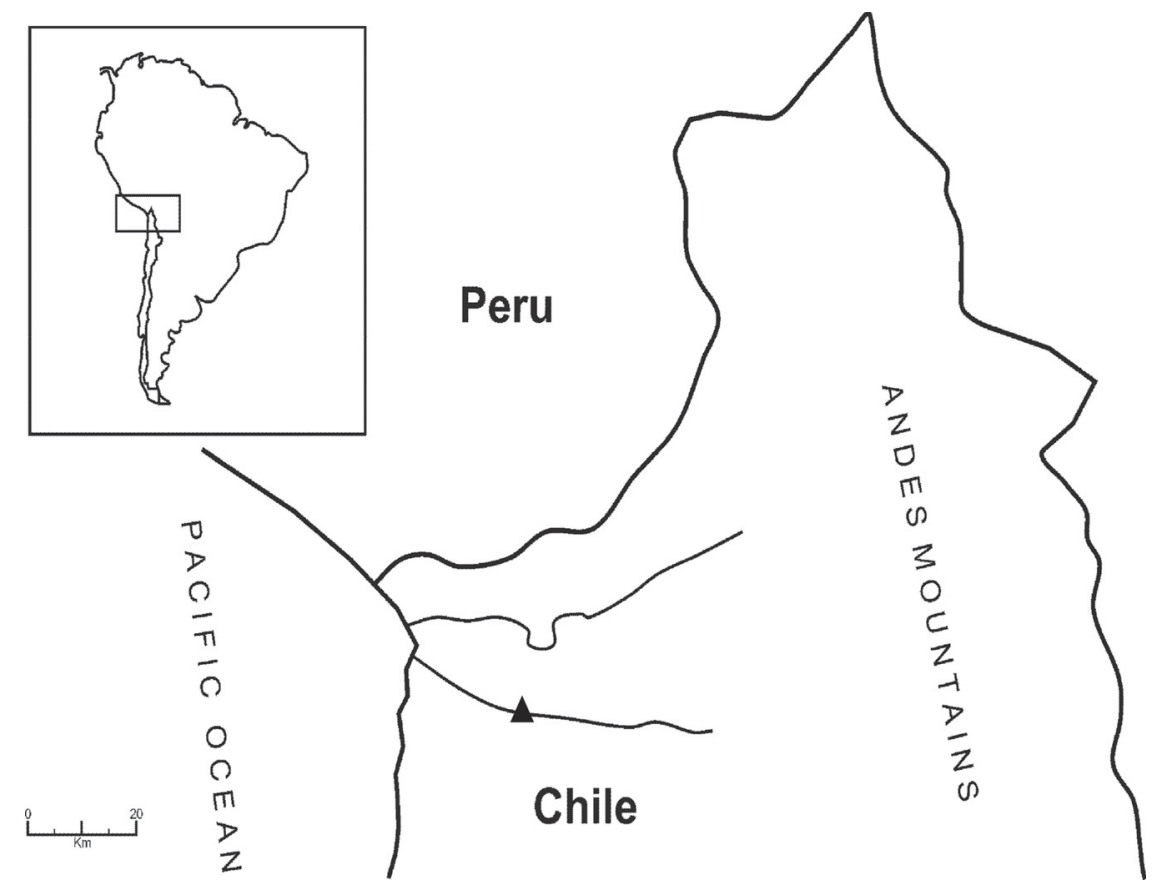

FIGURE 5. Geographic position of the first Chilean record of Homoeographa lanceolella (black triangle) in the Azapa Valley (18 $31^{\prime} \mathrm{S}$, $\left.70^{\circ} 10^{\prime} \mathrm{W}\right)$, Arica Province.

Figura 5. Posición geográfica del primer registro chileno de Homoeographa lanceolella (triángulo negro) en el Valle de Azapa (18³1’S, $\left.70^{\circ} 10^{\prime} \mathrm{W}\right)$, Provincia de Arica.

\section{ACKNOWLEDGMENTS}

I thank Bernard Landry for confirming the identification of the species and for valuable comments on a preliminary version; Joël Minet for sending photographs of the type material; Marcelo Vargas-Ortiz for editing the figures; Wilson Huanca-Mamani for providing the map and Lafayette Eaton for checking the English.

\section{BIBLIOGRAPHY}

HeInRICH, C. 1956. American moths of the subfamily Phycitinae. United States National Museum Bulletin 207:1-581.

Howden, A.T. 2008. The species of Pandeleteius Schoenherr of coastal Chile and Peru (Coleoptera, Curculionidae). Zootaxa: 1773:55-62.

Luebert, F. \& Pliscoff, P. 2006. Sinopsis bioclimática y vegetacional de Chile. Editorial Universitaria, Santiago, Chile. 316 pp.

Munroe, E. \& Solis, M.A. 1998. The Pyraloidea. p. 233-256. In: Kristensen, N.P. (ed.). Handbook of Zoology, Lepidoptera, Moths and Butterflies, vol. 1 Evolution, Systematics and Biogeography. Berlin \& New York, Walter de Gruyter, $\mathrm{x}+491 \mathrm{p}$.

Neunzig, H.H. 1994. New genera and species of Mexican Phycitinae (Lepidoptera: Pyralidae). Proceedings of the
Entomological Society of Washington 96:357-366.

Nuss, M., Landry, B., Mally, R., Vegliante, F., Tränkner, A., Bauer, F., Hayden, J., Segerer, A., Schouten, R., Li, H., Trofimova, T., Solis, M.A., De Prins, J.\& Speidel, W. 2003-2015: Global Information System on Pyraloidea. www.pyraloidea.org (accessed 07-05-2015)

Peña G., L.E. \& Ugarte P., A.J. 1996. Las mariposas de Chile. The butterflies of Chile. Santiago, Editorial Universitaria, $359 \mathrm{p}$.

PorTer, C.C. 1985. Trachysphyrus and the new genus Aeliopotes in the Coastal Desert of Peru and north Chile (Hymenoptera: Ichneumonidae). Psyche 92:513-545.

Stange, L.A. 1989. Review of the New World Dimarini with the description of a new genus from Peru (Neuroptera: Myrmeleontidae). Florida Entomologist 72:450-461.

VARGAS, H.A. 2013. Use of a native and an exotic Malvaceae by the little known skipper Pyrgus bocchoris trisignatus (Mabille) (Hesperiidae) in northern Chile. Journal of the Lepidopterists' Society 67:225-226.

Vargas, H.A. \& MundacA, E.A. 2014. First record of an exotic host plant for the oligophagous moth Macaria mirthae (Geometridae) in the coastal valleys of the northern Chilean Atacama Desert. Journal of the Lepidopterists' Society 68:292-295.

Vargas, H.A., Vargas-Ortiz, M., Huanca-Mamani, W. \& Bobadilla, D. 2013. First record of Acrocercops serrigera serrigera Meyrick (Lepidoptera: Gracillariidae) from Chile. Neotropical Entomology 42:112-114.

Recibido: 27.01 .16

Aceptado: 24.08.16 